Folia Histórica del Nordeste, N$^{0} 21$ (Resistencia, 2013) IIGHI, IH - CONICET, UNNE

\title{
EL “BENEFICIO DE LA LIBERTAD”. OBJETIVOS Y LÍMITES DE LAS POLÍTICAS REFORMISTAS EN LOS PUEBLOS GUARANÍES (1784-1801)
}

\author{
"El beneficio de la libertad". Objectives and limits of Bourbon Reforms \\ in Guaraní Missions (1784-1801)
}

\section{Lía Quarleri}

\begin{abstract}
Resumen
En las últimas décadas del siglo XVIII, el espacio misionero fue objeto de múltiples cambios, en gran medida por las presiones que desde el ámbito local y metropolitano se comenzaron a ejercer en relación a los intereses suscitados por los recursos y mano de obra de las reducciones guaraníes. En ese sentido, la expulsión de los jesuitas, producida dentro de un contexto político internacional, dio paso a la imposición de diferentes medidas de mayor control geo-político e intervención económica y demográfica en relación con nuevas dinámicas territoriales y mercantiles. Con los jesuitas expatriados, los borbones mantuvieron la estructura de pueblos y sus autoridades locales e introdujeron agentes de administración ajenos a las comunidades para disponer de los recursos y fiscalizar las actividades económicas. El nuevo régimen intensificó epidemias y fugas, altas tasas de mortalidad y un intenso deterioro de los establecimientos edilicios. Pese a todo, no fue hasta el 1800 que el gobierno virreinal, encabezado por Avilés, impulsó nuevas políticas sobre la población misionera dentro de una coyuntura renovada de concebir las relaciones coloniales. Dentro de esta línea, elaboró un sistema de liberación secuencial de las cargas comunales a ciertos guaraníes de misiones con el fin de transformar a los pobladores de las reducciones en tributarios independientes, productores autónomos y con fuerza de trabajo libre y accesible, mientras que el avance de colonos criollos sobre el espacio misionero era cada vez más evidente. En el presente trabajo, partiendo de los discursos esbozados en el proyecto mencionado y en las disputas existentes entre diferentes actores interesa dar cuenta, en especial, cómo se construyeron los marcos y límites de la libertad concedida a ciertos guaraníes y las contradicciones y limitaciones implícitas en el caso aquí estudiado.
\end{abstract}

$<$ Políticas indígenas $><$ pueblos guaraníes $><$ reformismo borbónico $>$

\begin{abstract}
In the last decades of the 18th century, the Guarani missions were the subject of multiple changes, largely because of pressures from the local and metropolitan contexts in what regards resources and labor from the Guarani reductions. Hence, the expulsion of the Jesuits, produced under an international political context, imposed different measures of greater geo-political control, and demographic and economic intervention in relation to new territorial and commercial dynamics. After the expulsion of the Jesuits, the Bourbons kept the structure of missions and local authorities, but they introduced new agents to supervise
\end{abstract}


the economic activities. This new regime produced grave epidemics, high mortality rates and a severe deterioration of the settlements. Nevertheless, it was not until 1800 that the Viceregal Government, headed by Avilés, introduced new demographic policies. A system of sequential release of communal charges to certain Guarani people from the mission was drawn up in order to transform the inhabitants of the reductions in a kind of independent producers and accessible labor. Besides, the advance of the criollo settlers on the territory was increasingly evident. In this paper, we analyze how the frames and limits of freedom granted to certain Guarani were built. The study is based on the discourse outlined in the mentioned project and on the disputes existing among the different actors involved.

$<$ Indigenous policies $><$ guarani missions $><$ bourbon reforms $>$

El colonialismo español en América desde su temprana implementación fue alterando, en diferentes formas y grados, las bases de organización políticodemográfica de las sociedades indígenas. El impacto diferencial estuvo relacionado con los ciclos de conquistas y guerras, con las ideologías de dominio, los modelos económicos imperantes y con las características situacionales y tipo de respuestas de cada grupo étnico o parcialidad. En el caso de los guaraníes, localizados a lo largo de los ríos Paraná, Uruguay y Paraguay, dependiendo del área, entraron tempranamente en la lógica del dominio europeo formando parte, directa o indirectamente, de la consolidación o expansión del mismo. Esto por dos grandes cuestiones. Por un lado, porque el tipo de organización aldeana, la localización en tierras fértiles sobre ríos navegables y la disposición de alimentos atrajeron, la instalación de los europeos en la región. Mientras que la ubicación de estas sociedades en un área disputada por los portugueses y españoles, sumado a la tradición y a la capacidad bélica de estos grupos, llevó a la instauración de diversos proyectos coloniales destinados a políticas bélicas. Al respecto el complejo jesuítico-guaraní erigido junto a sus milicias, en las actuales fronteras de Argentina, Paraguay, Uruguay y Brasil, a principios del siglo XVII, conformó durante un siglo y medio el principal medio defensivo de la corona española. Durante ese extenso período la política indígena aplicada sobre los treinta pueblos de misiones no tuvo grandes alteraciones, en la medida que estuvo regida casi exclusivamente por los jesuitas en base a ciertas pautas de negociación con los guaraníes, por un lado, y con el gobierno metropolitano, por el otro.

No obstante, en las últimas tres décadas del siglo XVIII, las reducciones fueron objeto de múltiples cambios, en gran medida, por las presiones que desde el ámbito local y metropolitano se comenzaron a ejercer en relación a los intereses suscitados en los recursos y mano de obra misionera. En ese sentido, la expulsión de los jesuitas, producida dentro de un contexto político internacional, dio paso a la imposición de diferentes medidas de mayor control geo-político e intervención económica y demográfica en relación con nuevas dinámicas territoriales y mercantiles. Con los jesuitas expatriados, los borbones mantuvieron la estructura de pueblos y sus autoridades locales e introdujeron agentes de administración ajenos a las comunidades para 
disponer de los recursos y fiscalizar las actividades económicas. El régimen misionero bajo la supervisión de los administradores dejó como secuela un intenso deterioro de los establecimientos edilicios, una fisura en el sistema de reproducción comunal, ciclos de epidemias y fugas, y altas tasas de mortalidad, entre otras cosas. Al respecto, si bien durante el gobierno de los jesuitas hubieron períodos de contracción económica, fugas y epidemias, existe un acuerdo en sostener que la expulsión de los jesuitas acentuó la "decadencia misionera" ${ }^{1}$.

Pese a la seguidilla de críticas, no fue hasta el 1800 que el gobierno virreinal, encabezado por Avilés, impulsó nuevas políticas sobre la población misionera dentro de una coyuntura renovada de concebir las relaciones coloniales, bajo la influencia cada vez más creciente de las doctrinas mercantilistas, iluministas y utilitaristas. En particular, en lo que tocaba a los pueblos guaraníes, el gobierno virreinal en sintonía con el metropolitano elaboró un sistema de liberación secuencial de las cargas comunales a ciertos sujetos, en general jefes de familias con el fin de transformar a los pobladores de las reducciones en tributarios independientes, productores autónomos y mano de obra libre, mientras el avance de colonos criollos sobre el espacio misionero era cada vez más evidente. El proyecto fue recibido de forma positiva por los guaraníes reducidos como una forma de desvincularse de las cargas laborales, los abusos y la violencia, así, como por gran parte de los funcionarios consultados, en general comisionados, curas, y tenientes de gobernador. Estos últimos, apoyaron la idea de desarticular el sistema de comunidad entre los treinta pueblos, inspirados por un particular espíritu "liberal", pero también guiados por intereses económicos concretos.

Las medidas tomadas después de la expulsión de los jesuitas y en especial las llamadas "Reformas de Avilés" han ocupado un lugar privilegiado en la literatura de misiones (Ganson, 2003; Hernández, 1999 y 2002; Maeder, 1992; Mariluz Urquijo, 1953 y [1964] 1987; Poenitz y Poenitz, 1998; Sarreal, 2008; Susnik, 1966 y Wilde, 2001 y 2003, entre otros). Sin embargo, no se han analizado como parte de un entramado más complejo de políticas, ideologías e intereses. Al respecto se pretende rescatar cierta línea de la historiografía brasilera que ha dado un lugar relevante a los cambios finiseculares concibiendo las "fronteras de la libertad" de las políticas indígenas del período estudiado (Alvarez Iglesias, 2012; Cunha y Farage, 1987; Frühauf García, 2007 y Melo Sampaio, 2012).

Para la historiografía especializada, los motivos o coyunturas que impulsaron esta reforma fueron diversos. En su estudio sobre el proceso de disolución suscitado tras la expulsión de los jesuitas, Edgar y Alfredo Poetniz, hacen especial hincapié en que el proyecto de Avilés fue diseñado en el contexto de alarma sobre el estado de abuso y deterioro del sistema misionero, tras tres décadas de gobierno y administración

\footnotetext{
${ }^{1}$ Esta decadencia está relacionada con la pérdida patrimonial y territorial, el desgaste institucional, los conflictos y abusos y con el descenso demográfico de la población misionera, por la alta mortalidad y por la fuga y deserción de familias e individuos hacia ciudades, haciendas y estancias. Véase, por ejemplo, para el período, los trabajos de referencia de Maeder, 1992, Mariluz Urquijo, 1953 y Poenitz y Poenitz, 1998.
} 
pos-jesuita (Poetniz y Poetniz, 1998). Ernesto Maeder, por su lado, afirma que Avilés ya venía con la idea de derogar el sistema de comunidad en los pueblos, imbuido en parte de un fuerte anti-jesuitismo, y de reemplazarlo por la liberación progresiva de la población misionera, pero bajo "el celoso control del gobierno" (Maeder, 1992: 202). No obstante, Juan Hernández, quien le dedicara un análisis pormenorizado al tema, afirma que con las reformas de Avilés se buscaba en parte, modificar el régimen de propiedad de la tierra, así como el libre acceso a los bienes y a la mano de obra de los pueblos (Hernández, 2002). Finalmente, Guillermo Wilde, al retomar el tema enfatiza en la relación entre el régimen de liberación y la política de asimilación de la población misionera, que venía gestándose desde la expulsión de los jesuitas, así como en las contradicciones entre el proyecto de Avilés y las prácticas de movilidad indígena (Wilde, 2003).

Partimos de la idea de que todos los factores mencionados contribuyeron a la cuestión, mientras que de forma particular, pretendemos comprender el imaginario y la ideología que alimentaba las nuevas prácticas, así como las contradicciones implícitas para lo cual repararemos en los discursos y en la terminología utilizada por algunos funcionarios locales para sostener la defensa de la liberación de los indios del sistema de comunidad. Interesa dar cuenta de la construcción de la idea de liberación comunal en base a conceptos renovados así como matrices de pensamiento asociadas a un liberalismo políticamente controlado. Esto redundó en conceder la libertad a ciertas familias bajo estrictas consignas y expectativas y en que, una vez en práctica el sistema, se multiplicasen los conflictos. Al respecto, la literatura brasilera será de enorme contrapunto ya que en su estudio sobre la legislación indígena de la segunda mitad del siglo XVIII ha dado cuenta de todos los vaivenes así como de las aristas de lo que se ha dado en llamar "sistema tutelar" (Melo Sampaio, 2012). En el presente trabajo, partiendo de los discursos esbozados en el proyecto mencionado y en las disputas existentes entre diferentes actores por la implementación del mismo, buscamos relacionar las políticas de liberación de las cargas de comunidades con los intereses políticos y económicos regionales y metropolitanos y dar cuenta del entramado de concepciones en relación con el estatus, derechos y condiciones forjadas sobre las poblaciones indígenas en general y sobre los guaraníes en particular. Interesa en particular, dar cuenta cómo se construyeron los marcos y límites de la libertad concedida y las contradicciones y limitaciones implícitas en el caso aquí estudiado².

\footnotetext{
${ }^{2}$ La documentación analizada en este trabajo se encuentra disponible en el Archivo General de la Nación, Salas VII y IX, y en particular en un copioso legajo donde se consignan las respuestas de administradores y curas a las consultas del marqués de Avilés, se exponen dudas o inconvenientes surgidos durante la implementación del sistema, también conflictos en la interpretación de la ordenanza, mensuras de tierras, listas de sujetos a quienes se les dará la libertad en primer término así como pedidos de los propias cabildos o autoridades de los pueblos. A su vez, el material citado y consultado se encuentra disponible en la edición de 1914 del informe del secretario del marqués de Avilés, Miguel de Lastarria, donde constan las propias impresiones de este último sobre la implementación del sistema de comunidad, así como las ordenanzas del propio Avilés y las respuestas de algunos pueblos a las mismas, entre otros temas diversos tocantes al comercio y a la defensa de las regiones del Plata.
} 


\section{Políticas poblacionales y fronterizas}

Las misiones jesuitas de guaraníes, a principios del siglo XVII, fueron localizadas en un territorio estratégico en relación con la frontera luso/española y se crearon con poblaciones tradicionalmente vinculadas a los conflictos con otros grupos, como los tupí, grupos que con la colonización portuguesa quedaron vinculados a su área de influencia. Desde la fundación de las primeras reducciones y con la designación de éstas como milicias del Rey para la defensa de la frontera con Portugal, en 1639, las mismas fueron creciendo como complejo productivo y comercial y obteniendo prerrogativas en la exención impositiva como en la extensión territorial. Si bien durante la administración jesuita hubieron períodos de crisis, epidemias, fugas y guerras, la población reducida en las treinta misiones, alcanzó el número de 150.000 personas hacia 1750, un número relevante de población para el contexto de la época mientras que el espacio misionero se mantuvo como núcleo económico destacado. Poco después, la llamada "guerra guaranítica" (1753-1756), y otros procesos fronterizos provocaron cierto grado de dispersión y descenso demográfico, de tal forma que hacia la época de expulsión de los jesuitas y comienzos del nuevo régimen misionero se contaba con un total aproximado de 88.800 habitantes (Maeder, 1992).

Tras la expulsión de los jesuitas, el complejo reduccional comenzó a cambiar en lo que hace a su dinámica interna, sus relaciones económicas, usos y ocupación de las áreas productivas, demografía, mestizaje y formas de acceso a la mano de obra, entre otras cosas. Al respecto, se pueden diferenciar etapas relacionadas con ciertas políticas, con determinados procesos demográficos, económicos y territoriales y con el tipo de respuestas de la población misionera. Una primera etapa -extendida a lo largo de la década de 1770 y comienzos de la siguiente- estuvo marcada por la puesta a prueba del nuevo régimen de administración reduccional, tras la expulsión de los jesuitas, que tendría como resultado el descenso demográfico, la consolidación en el poder clientelar local de los administradores criollos o españoles y algunos miembros de la elite indígena de los cabildos, acarreando la malversación y el abuso sobre la población indígena comunera. A esto se sumó el aumento de la demanda de rubros comerciales (cueros especialmente) y la ocupación de los contornos misioneros por parte de una población de diversos orígenes, que interesada en la explotación ganadera, fue drenando ese recurso entre otras cosas. Esta etapa coincidió con una política más agresiva de defensa y ocupación de territorios por parte de la Corona española, bajo la cual se envío al Río de la Plata una expedición de guerra al mando de Don Pedro de Ceballos que desencadenó un breve período de enfrentamientos armados entre ambas potencias. Estos conflictos concluyeron con la negociación del cese de hostilidades para lo cual se firmó, el 1 de octubre de 1777, el Tratado Preliminar de límites de América Meridional, conocido como Primer Tratado de San Ildefonso, que secundaba a su predecesor el Tratado de Permuta de 1750.

El Régimen misionero establecido inmediatamente después de la expulsión de los jesuitas, en 1768, fue asentado a partir de las instrucciones del gobernador Francisco de Paula Bucareli y Ursúa. En ellas se impulsó la configuración de un 
sistema de administración secular con la convicción que en la propia innovación descansaría el éxito del nuevo sistema de organización. Varios fueron los ejes de esta transformación, en lo que hace a las medidas sobre la población misionera. Uno de ellos, estuvo centrado en el paradigma de integración de la misma a la sociedad colonial, en contraste con la ideología precedente que avalaba la separación de indios y españoles en "dos repúblicas". El otro, estuvo centrado en la idea de "civilizar" a la población a través de la inculcación de determinados patrones culturales vinculados con la comunicación, la producción, la posesión de bienes y la comercialización, renovando con otro ropaje una ecuación ideológica de dominio que existió desde principios de la conquista de América. Sin embargo, para concretar estos objetivos, el nuevo régimen de administración secular mantuvo parte de la estructura que habían montado los ignacianos, con el fin de recrear alianzas con los caciques y con los cabildos indígenas así como las funciones de intermediación con los "indios del común” (Wilde, 2001).

Por todo ello, tras la expulsión, la administración colonial confirmó el sistema de pueblos, con sus cabildos y corregidores, y los atributos de distinción y autoridades de la elite indígena para montar sobre cada uno de ellos un mecanismo de gobierno, supervisión y control directo a partir de la designación de funcionarios laicos y de curas de diferentes órdenes religiosas para las tareas pastorales. A través de un gobernador, curas y administradores hispano-criollos se buscó implementar un conjunto de políticas reformistas en torno a la producción, comercialización, delimitación de fronteras, dinámicas demográficas y poblacionales. Se pretendió conformar colonias fronterizas que cumpliesen funciones productivas, mercantiles, defensivas y fiscales, fomentando la participación de los guaraníes en el mercado interno con sus productos y manos de obra. En un primer momento, Bucarelli designó a dos gobernadores para los treinta pueblos con el objeto de cubrir el amplio territorio, concretar visitas periódicas a las reducciones y dividir la defensa de la frontera ${ }^{3}$. No obstante, luego de varios desacuerdos, se designó a un único gobernador de los treinta pueblos de misiones, que pasó a quedar concentrado en la persona de Francisco Bruno de Zabala por treinta años. El territorio de las misiones se constituyó, a partir de las nuevas instrucciones, en una jurisdicción subordinada a la gobernación de Buenos Aires ${ }^{4}$.

Luego de un período inicial de caos $y$ descontrol en el uso de los recursos misioneros, y de conflictos en la frontera con Brasil, próxima al territorio reduccional,

\footnotetext{
${ }^{3}$ Por ese entonces al gobernador le preocupaba en particular "la frontera con los portugueses de Río Pardo". También las investidas de los indios del Chaco y de los charrúas. Carta de Francisco de Paula Bucareli y Ursúa al señor conde de Aranda, Buenos Aires, 14 de octubre de 1768. Archivo General de la Nación, Buenos Aires (AGN). Sala VII, Colección Biblioteca Nacional, Legajo 255, Documento 3634. Por su parte, hacia mediados del siglo XVIII los portugueses habían penetrado por un corredor de intercambio económico como de una avanzada militar hacia la gobernación de Santa Cruz de la Sierra, en la actual Bolivia, donde estaban las misiones de Moxos y Chiquitos (Rosas Moscoso, 2008).

${ }^{4}$ Tras la expulsión de los jesuitas, las treinta reducciones se mantuvieron bajo un mismo régimen divididos en dos distritos, el de Paraná y el de Uruguay, dentro de la jurisdicción de Buenos Aires. En 1774 se crearon nuevas agrupaciones llegando a estar los pueblos supeditados a los departamentos de Santiago, San Miguel, Yapeyú, Concepción y Candelaria. Con la Real Ordenanza de Intendentes Concepción y Candelaria pasaron a depender del Paraguay y los otros tres departamentos a Buenos Aires.
} 
se abrió un segundo momento que coincidió con el inicio de las tareas demarcadoras, en los nuevos dominios luso/españoles ${ }^{5}$. El desarrollo de estas actividades constituía un símbolo concreto de intervención metropolitana sobre el espacio, su observación y consiguiente elaboración de informes, que en cierto sentido marcó una presencia externa de supervisión de las administraciones locales como era el caso de las misiones guaraníes. Esto impulsó en alguna medida la alineación de altos funcionarios con los nuevos comisionados, lo que favoreció por ejemplo, que la acumulación de denuncias contra administradores se concretara en destituciones, pero generó presión sobre los recursos al evaluar las potencialidades del territorio misionero para fines productivos y comerciales con réditos para el erario. Dentro de esta línea, los comisionados de demarcación que permanecieron en América hasta principios del siglo XIX -sin éxito en relación a las consignas del Tratado de Límites- participaron en la elaboración de informes sobre la posible ocupación del territorio y la disposición de las llamadas tierras realengas, para extender el dominio productivo, sin considerar el uso previo del espacio por parte de la misiones. Esto concordaba con una importante avanzada desde la Banda Oriental y desde Corrientes sobre el territorio misionero ${ }^{6}$.

Para hacer efectivo el Tratado, las Coronas ibéricas ordenaron tareas de demarcación por medio de la designación de comisiones bilaterales que estarían encargadas, además, del estudio geográfico de la región ${ }^{7}$. Las tareas de delimitación y exploración que comenzaron en el año 1784 fueron efectivas para los intereses de la Corona en el incremento táctico del conocimiento geográfico, poblacional y botánico sobre ciertas áreas, no en lo que hacía a las actividades diplomáticas con los portugueses del Brasil. En particular, cuestiones como la explotación del territorio, la posesión de la tierra, los rubros de producción, los niveles de productividad, la división y organización del trabajo, conformaron la principal materia de registro. Paralelamente a estas exploraciones el avance de los criollos sobre el espacio misionero, considerado un "manantial de riquezas", era cada vez más una realidad, incentivada directa o indirectamente por los representantes metropolitanos, como parte de una política

\footnotetext{
${ }^{5}$ Estas tareas debían hacer efectivo el Tratado Límites de 1777 el cual consignaba que España conservase los siete pueblos de misiones y recobrara Colonia del Sacramento mientras que debía retirarse de la Isla de Santa Catalina y otros territorios en la colonia de Río Grande de San Pedro, ocupados recientemente por las fuerzas de Pedro de Ceballos.

${ }^{6}$ En el caso de los vecinos de Corrientes, hacia 1800, algunos de ellos -presentados a sí mismos como "hacendados"- solicitaron al virrey de Avilés que "disponga en la causa de límites" entre los territorios comprados "con su dinero al real fisco", ubicados entre el río Corrientes y el Miriñay (espacio hasta hace poco de influencia de los pueblos misioneros, especialmente del pueblo de Yapeyú), y las misiones, en una demostración de posicionamiento claro frente al avance mencionado. Carta de Sebastián de Almirón al virrey marqués de Avilés, Corrientes, 3 de febrero de 1800. AGN, Sala VII, Colección Andrés Lamas, Legajo $33, \mathrm{~s} / \mathrm{n}^{\circ}$ de documento, fojas 1 y $1 \mathrm{v}$.

${ }^{7}$ La Expedición a la América Meridional, al mando de José Varela y Ulloa, partió de Lisboa en enero de 1781. Una vez en el Río de la Plata, por orden del Virrey, la Expedición fue dividida en cuatro partidas bajo el mando de José Varela y Ulloa, Diego de Alvear, Félix de Azara y Juan Francisco de Aguirre. En ellas participaron botánicos, naturalistas, cartógrafos, ingenieros y marinos, lo cual dio inicio a una intervención diferente sobre los territorios coloniales (Quarleri, 2011).
} 
de conformación de colonias fronterizas que cumpliesen funciones productivas, mercantiles y defensivas, sin gastos para el erario.

En este sentido, fueron en particular los comisionados de las partidas demarcadoras quienes en sus primeros informes estimularon la desarticulación del sistema reduccional y la transformación de los pobladores en campesinos, incentivando su participación en el mercado interno con sus productos y manos de obra. Estas ideas asentadas claramente en los informes de los comisionados borbónicos escritos en la década de 1780 inspiraron o se vieron reflejadas posteriormente en las políticas metropolitanas en torno a los guaraníes de las reducciones y su vinculación con las llamadas cargas de comunidad. Fue entre los años 1799 y 1801 que se inauguró un intenso debate, impulsado por el virrey Avilés, como intermediario de esta nueva oleada de políticas reformistas, sobre los beneficios de liberar paulatinamente a la población reduccional de sus obligaciones laborales comunales. Los informes resultantes dieron cuenta de una postura mancomunada en lo que hacía a los pueblos guaraníes del Uruguay y Paraguay (antiguas misiones jesuíticas), y no tanto, en lo que hacía a otros pueblos guaraníes. Detrás de ello se escondían no solo nuevas visiones sobre el destino de los pueblos, sino también diversos intereses económicos por parte de las autoridades locales, como asimismo, del lado de los guaraníes, una consideración de nuevas oportunidades, en un contexto de intenso desgaste, deterioro y abuso del sistema reduccional y su población.

\section{Libertad vs comunidad: el discurso ilustrado y sus contradicciones}

El régimen misionero en manos de los administradores había generado, como mencionamos, ciclos de epidemias y fugas, altas tasas de mortalidad y un intenso desgaste material, moral y socio/político ${ }^{8}$. Pese a ello, los administradores, ciertas autoridades del cabildo indígena y los comerciantes que circulaban por los pueblos, continuaron sacando el máximo provecho posible de los bienes disponibles y de la fuerza de trabajo indígena. Mientras tanto y pese al notable descenso demográfico de la población guaraní desde la frontera sur localizada en los establecimientos de Yapeyú, se expandió la frontera ganadera. Asimismo, las estancias de los pueblos mantuvieron una participación muy elevada en la comercialización de cueros vacunos y carnes saladas (Maeder, 1992 y Ponitz y Poenitz, 1998)․․

\footnotetext{
${ }^{8}$ La declinación de la población se debió a varios factores. Entre ellos afectaron las deserciones, los desequilibrios en la estructura de edades y sexos y la mortalidad elevada por epidemias de viruela que, aunque existieron en la etapa jesuita en casi iguales niveles, en este no alcanzó a ser compensada por la natalidad. La baja población fue analizada a lo largo del período 1768-1807, que inició con 88.828 habitantes y finalizó con 38.000, aproximadamente (Maeder, 1992).

${ }^{9}$ Al respecto, hacia 1800, el administrador del pueblo de Yapeyú en su carácter de representante legal solicitaba se designen a título particular terrenos o campos para los sujetos del pueblo que dispusiesen de "ganado regular" en una clara puja con los hacendados de Corrientes, en los que los intereses de los administradores no eran ajenos. Carta de José de Lariz, administrador del Pueblo de Yapeyú, al teniente de gobernador del Pueblo, Buenos Aires, 20 de marzo de 1800. AGN, Sala VII, Colección Andrés Lamas, Legajo $33, \mathrm{~s} / \mathrm{n}^{\circ}$ de documento, fojas 1 y $1 \mathrm{v}$.
} 
Ante el auge de una política de neto corte comercial que impregnó a la sociedad colonial y a la administración borbónica se levantaron voces diversas que cuestionaron el rendimiento y la eficiencia productiva de los establecimientos misioneros bajo la continuidad de un régimen comunal de productividad y trabajo. El "sistema comunal de bienes" propio del complejo reduccional guaraní, ahora condenado por los funcionarios borbónicos e ilustrados, consistía en una forma de administrar la producción, acceso y circulación de bienes asentada en la intersección de diversos modelos económicos. Al respecto, los jesuitas habían configurado en las misiones dos niveles de organización complementarios, en lo que hacía a la tenencia de la tierra, el trabajo, el acopio de recursos, el acceso y distribución de los mismos, que fueron denominados abambaé y el tupambaé, respectivamente. El primero consistía en una reinterpretación jesuita de las tradiciones guaraníes y se centraba en el trabajo familiar en una pequeña parcela, con el fin de garantizar la subsistencia doméstica a través del cultivo de maíz, legumbres y mandioca. Por su parte, el segundo, consistía en el trabajo conjunto en tierras de la comunidad o del pueblo, y era realizado por diferentes familias o parcialidades con el objeto de obtener, bienes para almacenar o satisfacer necesidades diversas relacionadas con eventos rituales, situaciones extraordinarias, como podían ser sequías o epidemias y con el mantenimiento de la administración político/religiosa de las reducciones. Esto último era garantizado, en general, a través de los réditos de la comercialización de estos bienes bajo el control de los misioneros. Ambos tipos de modelos de producción, distribución y consumo respondían a ciertas prácticas familiares y comunales de acceso a los recursos observadas entre los guaraníes pero reorientadas con el fin de alcanzar niveles de eficiencia, acumulación y bienestar asociados a la política de estratificación colonial, de misionalización jesuita y de racionalidad económica occidental.

Sin embargo, bajo el nuevo régimen misional el sistema no tuvo los resultados esperados para la administración borbónica, y por el contrario, se transformó en un sistema abusivo y coactivo de acceso a recursos y mano de obra. Esta contradicción fue explotada en sus informes por los funcionarios borbónicos enviados por la Corona, en la década de 1780, para cumplir con las consignas del flamante Tratado de Límites con Portugal. En sus escritos sobresalió su insistencia en la necesidad de desarticular el sistema de comunidad de bienes y adoptar en las misiones un sistema de libertad de comercio, posesión particular de bienes y acceso sin restricciones a la mano de obra indígena, con el objeto implícito, de dinamizar el mercado interno y los ingresos fiscales derivados. Con respecto al sistema de comunidad, Gonzalo de Doblas, teniente de gobernador de Concepción, afirmaba que

Estos pueblos, desde su reducción, se han mantenido y mantienen en comunidad; y aunque este método de gobierno sería útil a los principios, después no ha servido en mi concepto sino a impedir los progresos de policía y civilidad: los que subsistirán desde mismo modo, entre tanto no se mude de gobierno, dando entera libertad a los indios como dicta la naturaleza (Doblas, [1785] 1970: 35). 
Por su parte, Félix de Azara, insistía en los elementos que habían condicionado el desenvolvimiento de la propiedad privada, el estímulo a la producción y al desarrollo de las capacidades individuales para alcanzar metas propias dentro de la lógica del utilitarismo de la época. Azara decía:

De esto se colige, que los padres curas eran árbitros de los fondos sobrantes de las comunidades de los pueblos, y que ningún indio podía aspirar a tener propiedad particular. Esto quitaba todos los estímulos de ejercitar la razón y los talentos; pues lo mismo había de comer, vestir y gozar el más aplicado, hábil y virtuoso, que el más malvado, torpe y holgazán (Azara, [1809] 1941, p. 182-183).

Finalmente, Diego de Alvear, dejaba entrever la necesidad de limitar o desarticular el régimen comunal misionero dando cuenta que en estas condiciones no daba réditos a la Corona. Alvear consideraba que:

Si damos ahora valor a la administración de justicia, teniendo los indios privilegios de menores, y gozando de entera libertad de derechos y costos en los tribunales del reino, y estimamos lo que puede valer la conservación y defensa de sus países en tiempos de guerra, veríamos que las misiones, en el píe que se hallan, son muy gravosas al estado, y que solo se mantienen para aumento de la cristiandad (Alvear, [1791] 1970, p. 721).

Si bien estas ideas estaban presentes desde más de una década atrás fue con la llegada del Virrey Avilés, en 1798, que cobraron la forma de política reformista, asociada a la expansión pobladora criolla, a una explotación racional de los recursos y a una concisa contribución de los territorios coloniales hacia la metrópoli.

Avilés iniciaba su mandado como representante de una nueva clase de funcionarios ilustrados, liberales y absolutistas, deseosos de intervenir sobre las administraciones locales, que si bien controlaban abusivamente los resortes de los recursos públicos desde hacía largo tiempo, con los bienes de temporalidades de los ex jesuitas, habían encontrado oportunidades de desasnar sus ansias de lucro frente a una inoperante reacción de la Corona. Avilés, con una perspectiva general de los asuntos del virreinato, instó a revisar modelos de organización locales en vistas a imponer cambios claves para racionalizar la explotación de los recursos, la fiscalización de la población y garantizar también la ocupación de los espacios agrícola/ganaderos (Mariluz Urquijo, [1964] 1987 y Susnik, 1966). En su consideración puntual sobre los pueblos de indios de Paraguay y Río de la Plata abrió una serie de oficios dirigidos a averiguar el estado de los indios de misiones. Avilés buscaba: 
eficazmente saber el estado de los pueblos de las reducciones de indios, la condición en que se hallan, las causas de los abusos y los remedios que vuestra persona conceptúe convenientes (...) de qué subsisten o de que medios se valen para comer y vestir, si tienen lo necesario con seguridad de poderse mantener sus familias y si hay algunos tan diligentes $\mathrm{y}$ económicos que gozan de cierta abundancia o mayores comodidades bien sea aplicándose a la agricultura o a las artes mecánicas (...) si tienen capacidad para tratar y contratar sin ser engañados señaladamente de los españoles, cuál es la conducta de los que administran los bienes de comunidad y si estos administradores procuran más bien el aumento de sus particulares intereses que el de los pueblos (...) si la presente constitución o sistema que viven en los pueblos sujetos a comunidad de bienes les es perjudicial a los indios o será mejor adjudicarles a su dominios particulares para que subsistan y trabajen como los demás indios tributarios al Rey de estos dominios de América (...) me instruirá con todas las especificaciones de todos los males que padezcan esos infelices indios y cuantos medios a vuestra persona le ocurran conducentes a la tranquilidad, instrucción, libertad, propiedad, y comodidad que deseo gocen conforme a las piadosas intenciones de $\mathrm{SM}^{10}$.

Una vez, en su gobierno e informado de los diferentes intereses espurios que corrían en torno a los bienes de los pueblos guaraníes, inició una serie de consultas específicas y generales. La consulta fue remetida a los administradores, curas y demás autoridades de los treinta pueblos de misiones del Uruguay y Paraná, y a los pueblos de encomienda de la jurisdicción de Asunción, como a los recientemente fundados. Las primeras fueron dirigidas a un puñado de sujetos de confianza y las segundas al resto. En el primer grupo se encontraba Félix de Azara, quien ya contaba con quince años de experiencia en el lugar y con una suma de informes realizados durante sus viajes y reconocimientos por el Paraná y el Paraguay. En base a esto, Avilés le solicitó opiniones e informaciones sobre la situación de los pueblos, en una carta dirigida en abril de 1799. En ella el virrey afirmaba que:

Siendo conducente al buen gobierno de este virreinato que procurase adquiera yo noticias ciertas de su político estado actual por medio de sujetos imparciales y capaces de instruirme en este ministerio por conocimiento práctico

\footnotetext{
${ }^{10}$ El Marqués de Avilés al reverendo padre Fray Fernando Caballero, visitador de esta provincia, Buenos Aires, 19 de agosto de 1799. AGN. División Colonia. Sección Gobierno, Sala IX, Legajo 18.3.1, s/nº de documento, fojas 1 y $1 \mathrm{v}$.
} 
del terreno informado de que vs los tiene adquiridos muy particulares y exactos de esta y de la provincia del Paraguay (...) espero que con la ingenuidad que les es propia me informe cuanto sepa principalmente en lo concerniente a los pueblos de indios en las materias siguientes sin hacer público este encargo para evitar que la malignidad intente frustrar los piadosos fines que me estimulan ${ }^{11}$.

Las palabras de Avilés expresaban abiertamente el clima político de conflictos e intereses en torno al espacio misionero, así como su temor por no encontrar una vía despojada de aquellos para acceder a información pertinente. Sin embargo, si bien Azara contaba con mucha información que había recolectado incansablemente siguiendo su espíritu de fiel funcionario y amante de la ciencia natural, también representaba un modelo en boga de eficiencia, imparcialidad y capacidad. Siguiendo estos dos parámetros y en virtud de su proyecto de intervención sobre los pueblos guaraníes, Avilés manifestó su deseo de que Azara le informara, o diera su postura, sobre varios puntos tocante a la disposición de tierra, comercio, administración y gobierno. En este sentido buscaba saber sobre: 1) La extensión del terreno de la jurisdicción de cada pueblo 2) La actuación de los administradores hispano/criollos de los pueblos guaraníes en lo que hace a "su utilidad pública" y participación "dolorosa y fraudulenta" 3) Los medios útiles para "sacar a los indios de la opresión" 4) Conveniencia del comercio entre "españoles y naturales" 4) La "capacidad de los indios de comerciar por si solos" 5) Los beneficios o perjuicios del método de comunidad ${ }^{12}$. En gran medida, el virrey buscaba confirmar el perjuicio y los abusos que ocasionaban los administradores a los pueblos y sustentar con información valorada la necesidad de desarticular el sistema de comunidad. Por su parte Azara, que compartía esta idea, fue aún más concluyente en relación a su confianza en los beneficios de la asimilación de los guaraníes a la sociedad mayor y en su desvinculación con el sistema llamado de comunidad. Al respecto, como promotor acérrimo del modelo de integración, llegó a contemplar que las familias indígenas no solo sean liberadas de las cargas de comunidad sino, que "se gobiernen por las mismas leyes y maneras que los españoles campestres" pagando los mismos impuestos que estos ${ }^{13}$. No obstante, no sería en esta línea que se implementaría el nuevo modelo.

En un segundo momento, Avilés remitió sus consultas a una serie extendida de funcionaros. En términos generales, la mayoría, apoyó la idea de desarticular el sistema de comunidad entre los treinta pueblos antiguamente fundados por los jesuitas, en virtud, por un lado, del estado de deterioro de los pueblos y de las ideas vigentes de asimilación de la población indígena y, por otro lado, de los deseos desde lo local de alcanzar un acceso más libre a la riqueza del espacio misionero, por sus reservas

\footnotetext{
${ }^{11}$ Carta del virrey Avilés a Félix de Azara, Buenos Aires, 30 de abril de 1799. AGN. División Colonia. Sección Gobierno, Sala IX, Legajo 18.3.1, s/nº de documento, foja 1.

${ }^{12}$ Idem, fojas $1 \mathrm{y} 1 \mathrm{v}$.

${ }^{13}$ Carta de Félix de Azara al Rey, 28 de febrero de 1800 (En Susnik, 1966: 89).
} 
ganaderas, sus vías navegables, sus terrenos fértiles, sus montes abundantes en maderas para la construcción, como a una fuerza de trabajo experimentada en las actividades agrícolas o en los diversos oficios mecánicos o artesanales. En gran medida, la "ruina" de los pueblos, se adjudicaba al sistema de comunidad como una condena que con ella arrastraba todos los males ${ }^{14}$.

No obstante, hubieron quienes manifestaron posturas diversas, básicamente desde la jurisdicción de Asunción. En términos generales, en esa jurisdicción existió una resistencia a implementar el sistema en los términos establecidos por Avilés representada de forma radical por el gobernador Lázaro de Ribera quien se mostró detractor de toda reforma y definió como masónicas a las ideas de Avilés. Para justificar su postura contra-reformista el gobernador manifestó su falta de confianza en el régimen propuesto ya que consideraba que de suprimirse el sistema comunal, los guaraníes de los tavá pueblos se dispersarían para conchabarse en diversas jurisdicciones, al mismo tiempo que reproducía imágenes enraizadas y discriminadoras sobre los guaraníes como parte de una supra-categoría étnica, la de indio- al describirlos como "indolentes, ociosos, dados a las embriagues y a la mentira y a puras ventajas individuales" (En Susnik, 1966: 84). A pesar del gobernador, dentro de la propia jurisdicción de Asunción, se lanzaron voces menos extremistas en cuanto a los resultados de la desvinculación del sistema comunal en el caso de los guaraníes de los tavá pueblos. Este fue el caso del franciscano Inocencio Cañete, quien consideraba que "los naturales de estos pueblos de este gobierno de Asunción nombrados Yutí, Caazapa, Itapé, Yaguarón, Ita, Ipané. Guarambaré, Tobatí, Atira y Altos" estaban "tan civilizados que no es fácil que cualquier español los engañe", por lo cual decía, "se deduce que son capaces de manejar, conservar y aumentar por sí sus intereses", y se sumaba a la crítica del sistema de comunidad al afirmar que, "no puede haber suerte más odiosa ni situación más dolorosa al corazón humano que sin ser siervos estén en servidumbre trabajando y padeciendo" ${ }^{15}$.

Por su parte, sorprende el discurso y el contenido utilizado por algunos funcionarios locales para sostener la defensa de la liberación de los indios del sistema de comunidad ${ }^{16}$. A modo de ejemplo, pero también destacando una argumentación clara y ordenada, se encuentra la del fray Joaquín Corcio, cura del pueblo de San Javier (actual

\footnotetext{
${ }^{14}$ En un extenso informe el cura de Santa María la Mayor, describía el estado de "ruina y miseria" a causa de "las comunidades" e incluía desde cuestiones edilicias, económicas, hasta de integridad física y material de sus habitantes. Carta del fray José Felipe Sánchez del Castillo al Virrey Marqués de Avilés, Santa María la Mayor, 20 de septiembre de 1800. Archivo General de la Nación. División Colonia. Sección Gobierno. Sala IX. Legajo 18.3.1, s/nº de documento, foja 1.

${ }^{15}$ Carta del fray Francisco Inocencio Cañete al virrey marqués de Avilés, Asunción, 19 de noviembre de 1799. Archivo General de la Nación. División Colonia. Sección Gobierno. Sala IX. Legajo 18.3.1, s/nº de documento, fojas $1,1 \mathrm{v}$ y $2 \mathrm{v}$.

${ }^{16}$ Branislava Susnik afirma que Avilés había hecho circular entre todos los gobernadores interinos el manifiesto de Rousseau (Susnik, 1966). Al respecto, en algunos escritos se evidencia cierta terminología asociada con el mismo, además de citas directas al concepto de estado de naturaleza esgrimido por Rousseau, como en la carta del fray Francisco Inocente Cañete. Carta del fray Francisco Inocencio Cañete al virrey marqués de Avilés, op. cit., foja 1v.
} 
provincia de Misiones). En su respuesta al oficio del virrey Avilés, el cura argumentó que el sistema de comunidad era "perjudicial a los intereses de Dios, el Rey y los indios". Al referirse a estos últimos enfatizó en que el sistema de comunidad los privaba "del bien más apreciable para el hombre que es la libertad". A "falta de libertad", afirmaba, "les falta todo", y con ello, quedaban anuladas las posibilidades de "instrucción" y la "acción" de "elegir" oficio, quedando sujetos al "arbitrio" de los administradores. Por el exceso de obligaciones asignadas por las cargas de comunidad, explicaba, los padres no disponían de tiempo para "educar a la prole" y para "muchas cosas concernientes a la vida civil y política". De esta forma concluía diciendo que, "las comunidades", o sea el régimen misionero de entonces, al mismo tiempo que aparejaban "miserias $y$ calamidades" para su población, las impedía su inserción "civilizada" en la industria, el comercio, en las ciencias y en las artes y con ello su "utilidad" para "el estado y para la sociedad"17.

Detrás de estas condenas se podía ver, por un lado, un claro alineamiento con los paradigmas iluministas, mercantilistas y utilitaristas de la época, adaptados a una política regalista y absolutista de corte eclesiástica pero también una acusación directa a los administradores, los cuales no solo encarnaban situaciones de abuso y despotismo, sino también conflictos de intereses. En este sentido, los curas muchas veces en enemistad con los administradores se veían afectados por éstos, quienes les proveían del alimento diario a su antojo, y además no siempre facilitaban la concurrencia a misa por parte de la población reducida. Sin embargo, además del maltrato y del abuso que preocupaba a los funcionarios reales y a una parte de los religiosos, el tema que inquietaba desde una proyección más amplia, era que en este contexto los indios se fugaban de los pueblos y se conchababan con españoles de haciendas o en oficios varios en las ciudades, muchas veces volviéndose a casar, por lo que de esta forma quedaban fuera del control del estado y de la Iglesia. Esta libertad, optada por un número importante de guaraníes de los pueblos, en general hombres, no coincidía con las expectativas asentadas en la "política de libertad" diseñada por las autoridades metropolitanas y virreinales. En este sentido, el decreto de liberación de cargas comunales, establecido el 18 de febrero de 1800 , solo sería concedido, como veremos, de forma paulatina a quienes demostrasen o tuviesen ciertas disposiciones o características y, a partir de un pacto o compromiso con los beneficiarios del mismo, que garantizase las expectativas de productividad y autonomía esperadas.

\section{El "beneficio de la libertad": límites, objetivos y conflictos}

La liberación progresiva fue decretada tras varios meses de recepción de informes que -con excepción a los elaborados desde el gobierno del Paraguay en relación a los llamados Tavá pueblos que estaban encomendados a particulares- fueron optimistas en cuanto a los resultados futuros e inmediatos de las medidas propuestas

\footnotetext{
${ }^{17}$ Fray Joaquín Corcio al virrey Avilés, San Francisco Javier, 19 de julio de 1800. AGN. División Colonia. Sección Gobierno, Sala IX, Legajo 18.3.1, fojas 1, 1v.
} 
(Susnik, 1966). Éstas, concebían la idea de liberar a la población indígena del sistema comunal reduccional, como base de transformación del estado actual de los pueblos. Por su parte, se incentivaba el mestizaje ante la idea de que este contribuiría a fomentar la incorporación del castellano como lengua principal, y ciertos atributos y valores europeos en relación a las prácticas del trabajo, la acumulación y el comercio. Al respecto, Avilés esperaba que

que con la referida mi Providencia ultima se logrará avivar la energía de espíritu de los demás, y su aplicación á saber nuestra Lengua que ignoran generalmente; pues los que debían procurarlo, nada han adelantado, ni los Maestros de Escuela, que no han sido más que uno zánganos. Para facilitarles la practica instrucción civil, o del comercio, dispondré cuanto conduzca al cultivo particular de sus chacras, no como en tiempos de los Jesuitas, ni menos como ahora, si no justa, y fructuosamente ${ }^{18}$.

No obstante, se decidió finalmente optar por una medida progresiva que fuera evaluando los resultados observables entre aquellos que serían liberados del sistema comunal y una integración parcial, ya que seguirían pagando tributo como el resto de las comunidades indígenas del virreinato. De esta forma el "beneficio de la libertad" recaería sobre algunos pocos y, de su accionar posterior, dependería la liberación del resto. El virrey estipulaba que se les diese la "libertad como a los españoles" y se les restituyan:

sus propiedades individuales, la Patria potestad y que vivan con la seguridad establecida por aquellos principios y Leyes, pero que se ejecute con prudencia, según la aptitud que se descubra en cada uno; para evitar desordenes que se gobiernen por estas, que se observen también las ordenanzas del Perú en lo que sean adaptables y las de Bucareli en lo que convenga en estas críticas circunstancias de pasar de un Estado ignorante, rudo, y despótico, a otro ilustrado, libre, y regulado, cuyo paso no conviene sea repentino, progresivo; pero eficaz ${ }^{19}$.

Finalmente, "ascendiendo el numero de Almas de los treinta Pueblos Guaranís a 42.885 fueron declarados libres de los trabajos de Comunidad 6.212 hasta el 20 de

\footnotetext{
18 "Copia del informe que hizo a S.M. el Exmo. Señor Marqués de Avilés, Virrey de Buenos Aires sobre el Gobierno Temporal y Espiritual pasado y presente de los treinta Pueblos de las Misiones guaraníes, Buenos Aires, 8 de marzo de 1800" (Lastarria 1914: 47, Parte 1).

19 “Copia del informe que hizo a S.M. el Exmo. Señor Marqués de Avilés, Virrey de Buenos Aires sobre el Gobierno Temporal y Espiritual pasado y presente de los treinta Pueblos de las Misiones guaraníes, Buenos Aires, 8 de marzo de 1800" (Lastarria 1914, 45-46, Parte 1).
} 
Mayo de 1801,en cuyo día entregó el mando dicho Virrey"20. Los individuos liberados conformaban 323 familias, lo cual no trajo pocos problemas ${ }^{21}$.

La libertad fue concedida, en teoría, a ciertos jefes o cabezas de familias que reunían ciertas condiciones, a sus esposas, hijos e hijas y "demás parientes por una y otra línea asignada en el oficio" y fue recibida con agrado por parte de los beneficiados ${ }^{22}$. De esta forma quienes entraban en el nuevo sistema quedaban "exentos de todo trabajo y pensión de comunidad para que se manejen por sí como los españoles solo con la precisa obligación de exigir anualmente un peso de tributo, asistencia diaria de misa y frecuencia de sacramentos", además estos debían comprometerse a "educar a sus hijos política y cristianamente" y hablar el castellano, entre otras cosas ${ }^{23}$. Las familias exoneradas del régimen de comunidad pasaban a recibir terrenos en la jurisdicción de los pueblos, para lo cual, se realizaron diversas mensuras de tierras aptas para el cultivo. Además de lotes para chacras familiares, se les entregarían vacas y bueyes, herramientas para la agricultura como hachas, arados y machetes, y en el caso de los artesanos instrumentos y materiales así como se harían remesas o se darían "auxilios" de alimento por un año, hasta que la cosecha diese sus réditos. Varios fueron los funcionarios que afirmaron la buena recepción de los habitantes de los pueblos a las nuevas ordenanzas.

La lista de los beneficiados fue realizada, en la mayoría de los casos, por los curas y administradores de cada uno de los Treinta pueblos. Previamente a la selección, el virrey había solicitado:

20 “Apuntamiento de las Providencias libradas por el Virrey de Buenos Ayres, Marqués de Avilés sobre la variación del sistema del Gobierno en Comunidad de los Indios de los treinta Pueblos de Misiones Guaranís, en él de libertad, propiedad individual \&c.” (Lastarria 1914, p. 58, Parte I)

${ }^{21}$ Cabe aclarar que en ciertos pueblos no guaraníes fundados más recientemente en la jurisdicción de Corrientes también se evaluó la concesión de la libertad. Este es el caso del pueblo de Astos conformado por parcialidades guaycurúes. Relación del cura y vicario y administrador interino en este pueblo de Santa Lucía de los Astos, al señor subdelegado, en cumplimiento de la superior disposición. Santa Lucía de los Astos, 21 de febrero de 1801. AGN. División Colonia. Sección Gobierno, Sala IX, Legajo 18.3.1, $\mathrm{s} / \mathrm{n}^{\circ}$ de legajo, fojas 1 y $1 \mathrm{v}$.

${ }^{22}$ Por ejemplo, el hermano capellán del pueblo de Santa Rosa, contó en una carta al virrey que luego de leer "artículo por artículo con su idioma nativo guaraní, quedaron muy alegres por la libertad conseguida para sus hijos, hermanos y parientes por una y otra línea". Informe del capellán Cipriano Cañete al virrey Avilés. Santa Rosa, Departamento de Santiago, septiembre de 1800. AGN. División Colonia. Sección Gobierno, Sala IX, Legajo 18.3.1, s/n $\mathrm{n}^{\circ}$ de legajo, foja 1. Por su parte, en la tercera parte de la obra de Miguel de Lastarria se encuentran cartas en guaraní y en castellano donde algunos cabildos de los pueblos expresan al virrey su gratitud y entusiasmo por las nuevas órdenes y en algunos casos además expresaron que con tal medida "se los sacaba de la opresión en que tanto tiempo hemos vivido olvidados asimismo del paternal amor". Carta del corregidor y el cabildo del Pueblo de Santa María la Mayor al excelentísimo virrey, Santa María la Mayor, 20 de octubre de 1800. En Lastarria (1914: 368, tomo III). Cabe aclarar que si bien consideramos que la medida fue ampliamente agradecida por las autoridades de los pueblos guaraníes, no creemos que todos ellos hayan tenido una lectura homogénea y lineal de su propia historia.

${ }^{23}$ Informe de Alonso Cáseres al virrey Avilés. Trinidad, 24 de julio de 1800. AGN. División Colonia. Sección Gobierno, Sala IX, Legajo 18.3.1, s/n $\mathrm{n}^{\circ}$ de documento, foja 1. 
Que el Gobernador de Misiones Guaraníes remitiese listas exactas de los Indios que tuviesen la suficiente instrucción del trato civil, la penetración, pendencia y habilidad precisas para emprender sus trabajos y dirigirse en sus contratos, y la energía de espíritu para poder representar, o para mantenerse en el goce de sus naturales derechos, o que fuesen capaces de manejarse por si. Lo que demostrarían las propiedades con que se hallasen, y la comodidad y régimen de sus familias a pesar de la poderosa fuerza contraria de su abusivo Gobierno. Que también entendiesen nuestro idioma Español, que habría influido en sus costumbres y conocimientos. Y que por otra parte no fuesen notados de capciosos, o que prefiriesen vivir más bien del engaño, quede la buena fe, lo cual confirmaría haberse alejado de sus habitudes originarias o bárbaras ${ }^{24}$.

Por todo lo dicho, Avilés había establecido que solo podían ser designados como libres, aquellos que demostrasen "aplicación" a la agricultura y a la industria, convenientemente con oficios (herreros, tejedores, carpinteros, músicos, zapateros), que sepan "contratar honradamente", que estén instruidos en el idioma castellano, y que lleven una vida cristiana. Si bien en gran medida se dio el beneficio de la libertad a hombres casados, también se le concedió a sujetos solteros. Se privilegiaba a su vez que los individuos en quienes recaería la responsabilidad de direccionar la nueva empresa familiar fuesen "bastante castellanos" en sus costumbres. En el contexto de la época esto remitía a una forma de vida, vestimenta, y a ciertos códigos en el trato interpersonal como económico. La asimilación de estas particularidades en el caso guaraní misionero había estado asociada a la elite indígena que conformaba los cabildos y cuyos cargos de corregidores y alcaldes habían sido en general heredados en líneas familiares particulares, independientemente de los caciques de parcialidades. Con los jesuitas y tras las expulsiones de estos, los cabildantes constituyeron un sector próximo a las autoridades respectivas, supervisando el cumplimiento de trabajos y castigos asignados por los misioneros o administradores, según el período. Manejaban los códigos de ambos universos, pero actuaban muchas veces en función de intereses clientelares. Hablaban castellano y eran letrados, lo que les concedía un poder especial. Si bien el decreto de Avilés no apuntaba a liberar a este sector, en particular, la tendencia fue que los administradores los nombraron a ellos en primer lugar quizá con la especulación de obtener algún rédito futuro.

Varios fueron los motivos de conflicto, o las dificultades, que se suscitaron durante la implementación del sistema. Al respecto, Ernesto Maeder retoma los inconvenientes que se originaron por la extensión del sistema al resto de los guaraníes y

\footnotetext{
24 “Apuntamiento de las Providencias libradas por el Virrey de Buenos Aires, Marqués de Avilés sobre la variación del sistema del Gobierno en Comunidad de los Indios de los treinta Pueblos de Misiones Guaranís, en él de libertad, propiedad individual \& c.” (Lastarria 1914, p. 54, Parte I)
} 
el problema en la distribución de la tierra. En particular, destaca las fricciones generadas por el crecimiento de la población criolla circundante a las misiones que exigían espacios aptos para el desarrollo de sus actividades agropecuarias. Tal era el impulso expansivo, que sin mediar autorización, muchos vecinos habían ocupado tierras de las periferias de los pueblos, alegando ser realengas, y habían introducido animales y mejoras, tras lo cual comenzaron a alegar derechos de propiedad. Frente a ello, Avilés en su corto mandato, debió tomar posición aunque sin éxito, aduciendo prioridad de los pueblos sobre las tierras disputadas con los criollos o españoles (Maeder, 1992). Al respecto, Juan Hernández remarca la actitud de defensa de los derechos sobre la tierra y en particular de los yerbales y algodonales, que toman los guaraníes al solicitar la concesión de documentos por parte de las autoridades que legalicen su posesión "ancestral" (Hernández, 2002). Por su parte, también se dieron conflictos internos en la asignación de tierras ${ }^{25}$.

Otras de las grandes cuestiones que se suscitaron durante la aplicación de la nueva política, fue el alcance de la medida a la familia de quienes recibieron las cartas de liberación. En este tema reparó tempranamente Branislava Susnik, ya que como la carta de liberación se daba al jefe de familia extensa y a sus parientes, constituyó una referencia proclive a interpretaciones diferenciales (Susnik, 1966). Esta cuestión, no tardó en surgir como tema de disconformidad por parte de los individuos no implicados y como preocupación desde la administración. Uno de los temas que surgieron durante el proceso, fue la interpretación de las relaciones familiares que la administración hizo, en algunos casos, en contraste con las de los propios guaraníes. Al respecto el virrey escribía:

extraño mucho que a los mencionados cuarenta (...) que yo nombré de los pertenecientes al pueblo de Santiago (...) se les hayan querido agregar sesenta y seis a título de parentesco, lo cual ha provenido seguramente de la mala inteligencia de mis superiores ordenes" (...) dirijo con esto dicho una circular al señor gobernador de los treinta pueblos y fuera de otras prevenciones que deben quedar sujetos a comunidad aquellos indios que aunque parientes de los nombrados por mi libres carecen de las demás calidades que exigen previamente mis superiores disposiciones (...) el total de

\footnotetext{
${ }^{25}$ Para determinar que tierras se darían a los sujetos liberados y a sus familias se realizaron mensuras en casi todos los pueblos que fueron encargadas a los administradores u otros sujetos. Sin embargo, este trabajo se hizo con irregular resultado, por la dedicación que implicaba, como así también por las resistencias que de forma interna en algunos casos se suscitaron. En la documentación abundan menciones a estos temas. En especial llama la atención el caso del pueblo de San Carlos donde el cura aparentemente se resistió a conceder la libertad a dos muchachos que tenía "bajo su protección" y entonces hasta no resolver la situación el teniente de gobernador de Concepción suspendió la entrega de tierras a estos dos sujetos. Carta de Feliciano de Correa, Teniente de gobernador de Concepción al virrey marques de Avilés, Apóstoles, 22 de noviembre de 1800. Archivo General de la Nación. División Colonia. Sección Gobierno. Sala IX. Legajo 18.3.1, documento n 235, foja 1.
} 
los indios merecerá la libertad después que los que la hayan alcanzado demuestren con su conducta y trabajo los buenos efectos que me prometo $^{26}$.

Esta cuestión que había sido también descripta por José María Mariluz Urquijo (1964), daba cuenta de que los límites al parentesco no era algo que se podía aplicar desde afuera y de forma cerrada. También, que una medida impuesta con criterios concebidos desde la administración colonial sobre lógicas de homogeneidad y exclusión, generarían conflictos internos en una sociedad estratificada y diversa. Por su parte, la medida fue interpretada en sus propios términos por los guaraníes beneficiados y no beneficiados, lo que implicó que sin mediar un tiempo de adaptación previsto por el decreto, que en cierto modo quedaba en manos de la subjetividad de las autoridades, aquellos solicitaran la liberación del resto de los habitantes de los pueblos. Sin embargo, esto fue complejo de manejar dadas las lógicas expectativas que generó entre los comuneros ${ }^{27}$. Conscientes de que existían premisas para continuar con el sistema de liberación, aquellos que solicitaron la extensión, lo hicieron con argumentos positivos en torno a sus primeros resultados. Al respecto, pese a que sólo habían pasado siete meses desde el decreto, bajo la firma de varios integrantes y autoridades del pueblo de San Juan se relataba que:

los cincuenta individuos que con nuestras familias hemos sido sacados de comunidad mediante la benignidad quedamos disfrutando de dicha gracias (...) siendo contante que desde un año y menos (...) cesó la deserción diaria que nuestros parientes y paisanos ejecutaban anteriormente por falta de socorros, lo que participamos a vuestra excelencia suplicándole haga partícipe de cual gracia a los que restan que así lo deseen ${ }^{28}$.

Las argumentaciones esbozadas para solicitar la extensión de la desvinculación del sistema de comunidad a aquellos "parientes y paisanos" que lo desearan, se sostenía en la baja de deserción, sin embargo en este punto como en tantos otros la alegación dada no coincidía en todo con las expectativas de las autoridades. La "libertad" no solo había sido concebida desde ciertos parámetros y restricciones por el Virrey y

\footnotetext{
${ }^{26}$ Los cuarenta a los que se refería se sumaban a otros 709 designados en calidad de libres en dicho pueblo. El virrey Avilés al cura de Santiago, Buenos Aires, 30 de noviembre de 1800. Archivo General de la Nación. División Colonia. Sección Gobierno. Sala IX. Legajo 18.3.1, foja 1.

${ }^{27}$ Un representante del pueblo de San Cosme y San Damián, Baltazar Anta, relataba en su carta de julio de 1800 que "con mucho respeto recibió la justificada deliberación y providencia a favor de estos naturales" mientras contaba que aquellos que "aún no gozan de la gracia, se esfuerzan a fin de conseguirla". Carta de Baltazar Anta al virrey Avilés, San Cosme, 23 de julio de 1800. Archivo General de la Nación. División Colonia. Sección Gobierno. Sala IX. Legajo 18.3.1, s/nº de documento, foja 1.

${ }^{28}$ Carta del Pueblo de San Juan Bautista al virrey Avilés. San Juan 18 de septiembre de 1800. Archivo General de la Nación. División Colonia. Sección Gobierno. Sala IX. Legajo 18.3.1, s/nº de documento, foja 1.
} 
sus asesores, en contraposición a ideales más amplios como los esbozados por Azara por ejemplo, sino que contemplaba una contrapartida concreta que era la autonomía productiva, la productividad y la eficiencia adaptativa de las familias liberadas. Esta visión, se contraponía con la de aquellos beneficiados por el sistema, que sostenían la necesidad de los "socorros" para fortalecer la permanencia de las familias en las nuevas parcelas. Finalmente, otro tema de conflicto fue el de la residencia fija en las nuevas parcelas pretendida por las autoridades. Al respecto, Branislava Susnik menciona que, tras la liberación algunas familias se fueron instalando en la periferia de la población rural, en concordancia con formas propias de asentamiento de los guaraníes, en tiempos misionales (Susnik, 1966: 91). En este asunto, Guillermo Wilde se sumó al debate, indagando sobre los diferentes significados de libertad para las partes en juego, al remarcar el "paradigma de movilidad" que detentaban los guaraníes misioneros en sus lógicas de apropiación del espacio (Wilde, 2003: 85-86).

Tal como se describió, fueron múltiples los niveles de desacuerdo y conflictividad que se fueron dando en un proyecto que se venía sopesando desde varias décadas atrás. Asimismo, en 1801, Avilés dejó su cargo de virrey del Río de la Plata, para asumir el mismo cargo en el virreinato del Perú y, ese mismo año, España declaró la guerra a Portugal e inmediatamente después los luso/brasileros tomaron militarmente el departamento de San Miguel, ubicado en la margen oriental del Uruguay, en donde había siete pueblos de origen jesuítico-guaraní. Ello conllevó para la corona española, la pérdida de una porción sustancial del territorio y de unos 12 mil vasallos. En 1803, con 23 pueblos se creó el Gobierno militar y político de Misiones con independencia de los gobernadores de Buenos Aires y Paraguay, y por cédula real, se decretó la libertad de todos los indios misioneros, y la distribución de todos los bienes de las reducciones (Poetniz y Poetniz, 1998). Por su parte, la ocupación militar del territorio oriental de las misiones cambió la óptica desde la cual se había pensado la relación con los pobladores de las misiones en tanto productores.

A partir de ello, el problema que se instaló fue cómo conciliar las políticas de liberación de cargas laborales e impositivas que recaían sobre la población misionera, concebidas previamente por el virrey Avilés, con el poblamiento y defensa del territorio misionero. En este nuevo contexto, se observó en manos del nuevo gobernador político y militar de misiones, Joaquín de Soria y Santa Cruz una vuelta a políticas antiguas de control de la circulación de la población y de su convivencia en los pueblos de misiones. De esta forma, en 1803, Soria encargó "a los corregidores, cabildos y administradores de cada pueblo, procuren por todos los medios posibles evitar los amancebamientos, vicios lujuriosos", al mismo que prohibió "el tránsito por estos pueblos a todo sujeto del estado o calidad que sea que no lleve su correspondiente pasaporte o licencia por escrito"29. En contraste con la política de apertura plasmada por Avilés, la situación

${ }^{29}$ Bando de policía dictado para los treinta pueblos de misiones por Don Joaquín de Soria y Santa Cruz, gobernador político y militar de los pueblos de misiones del Uruguay y Paraná y subdelegado de la Real Hacienda, Cuartel General de San Carlos, 11 de diciembre de 1801. AGN, Sala VII, Colección Biblioteca Nacional, Legajo 290, documento 4450. 
bélica y la diversificación de respuestas por parte de la población de las misiones, en ese entonces compuesta por una mayoría indígena, instauró la búsqueda de un límite a la circulación y a la libre convivencia.

\section{Libertad indígena o nuevos criterios de dominio: reflexiones finales}

Desde la imposición del sistema colonial en el Río de la Plata, ciertas parcialidades guaraníes entraron en relación con las monarquías luso/españolas y sus instituciones intermedias. A partir de entonces, ciertos niveles de negociación y de imposición de lógicas de dominio y protección se fueron entrecruzando, de acuerdo al contexto, y a la diversidad de respuestas y posibilidades de acción político/bélica de los propios grupos locales. Así, las parcialidades guaraníes que quedaron bajo la esfera de poder de los conquistadores de la antigua jurisdicción del Paraguay fueron dados en encomienda, a partir de la década de 1550, y en ese sentido un conjunto de ordenanzas se fueron gestando para regular o mediar en la relación entre los encomenderos y los grupos encomendados, con escasos resultados en relación a los límites en torno a los abusos de la población reducida. Por su parte, en las áreas de la cuenca del Plata y en virtud de la frontera con Portugal, la Corona española promovió otro tipo de interacción con las poblaciones guaraníes reducidas por los jesuitas, que generó otro modelo de carácter más cerrado que luego fue dado en llamarse sistema de comunidad. En este sentido es que no puede hablarse de una "legislación indígena" uniforme, ni tampoco de criterios ideológicos integradores en las políticas de interpelación con las poblaciones indígenas en el Río de la Plata. Al respecto, la legislación indiana referida a los pueblos de indios o a los grupos indígenas no dominados fue el resultado de ordenanzas generadas, ante situaciones coyunturales o concretas, que generaron una enorme casuística que respondía a temas diversos sin criterios de unidad y coherencia mayor.

Este desorden normativo, no ha sido un tema menor en la historia de los pueblos indígenas de América en general y entre las parcialidades guaraníes en particular, más aún, al constituirse estas últimas en conglomerados poblacionales extensos, con hábitos semi/sedentarios y horticultores, localizados -como ya mencionamos- en áreas claves por sus vías fluviales, tierras fértiles y cercanía relativa al puerto de Buenos Aires, que las tornó en sujetos vulnerables de políticas coloniales y económicas diversas. Con esto, las ordenanzas, las medidas y las legislaciones elaboradas en relación con estos pueblos no respondieron a "políticas indígenas" estructurales, sino a los resultados del entrecruzamiento entre ciertas pautas de protección que la Corona debía sostener, para mantenerse como referente de la relación patriarcal instituida, de intereses fiscales y defensivos concretos, de concesiones estratégicas dadas a los actores locales, sean estos encomenderos, colonos, autoridades administrativas, jesuitas o guaraníes y finalmente, también en función de los vaivenes de las relaciones con los vecinos fronterizos, los portugueses y los indios infieles. Al respecto, tras el Tratado de Madrid y el conflicto posterior por la resistencia jesuítica-guaraní, a entregar las tierras de los siete pueblos 
orientales cedidas a los portugueses por la Corona española, a cambio de colonia de Sacramento, la Corona española no dudó en exponer a los pueblos indígenas dentro de este lábil contexto de negociación con los lusitanos (Quarleri, 2009).

El traspaso de la administración de los pueblos jesuitas a la administración colonial, tras la extradición de los mismos, abrió una nueva etapa en lo que hacía a la configuración normativa. Hasta entonces, en gran medida, las regulaciones habían estado en poder de la Compañía de Jesús y la Corona se había limitado a dirimir conflictos entre las reducciones jesuitas y otros grupos y a extender o cercenar los derechos y obligaciones de las mismas en relación a tierras y cargas fiscales. En contraposición, la instauración de un nuevo régimen misionero fue acompañado de un conjunto de ordenanzas que pretendieron regular la organización administrativa, política y económica, por un lado, bajar directrices claras en torno a las nuevas políticas demográficas, de residencia, comercio y mestizaje, por el otro, y maximizar la producción, comercialización de los bienes surgidos de la explotación comunal de la tierra y la mano de obra ${ }^{30}$. De esta forma, con el nuevo régimen se mantuvo la estructura dual de posesión y explotación de la tierra, comunal y familiar, para finalmente destinar las tierras de comunidad a la producción de excedentes en base a la fuerza de trabajo de los "indios del común" viabilizada por los caciques para el propio mantenimiento de los pueblos, como para generar ingresos por la comercialización y para el pago de salarios y obligaciones fiscales. La apertura y el fomento al comercio, la autorización a radicarse en tierras de los pueblos a forasteros, en general criollos, y la incorporación de administradores, implicó una novedad vislumbrada en la normativa sobre las relaciones hispano/indígenas en los pueblos guaraníes, como la base de las futuras contradicciones que propiciará las críticas al sistema, y más tarde, el proyecto de liberación de cargas comunales.

Al respecto, la combinación de algunos rasgos del modelo jesuítico previo, denominado por la administración borbónica, "sistema de comunidad" con elementos nuevos, dentro del llamado "paradigma de asimilación", por la historiografía especializada, dio por resultado una ecuación letal para la integridad demográfica, material y moral de la población misionera (Quarleri, 2012). En consecuencia, hacia la década de 1780, el llamado sistema de comunidad pasó a cargar con todos los males, en un artilugio discursivo e ideológico, primero en manos de funcionarios borbónicos como los comisionados de demarcación, Félix de Azara y Diego de Alvear, y más tarde, en poder de los propios actores que llevaron al régimen comunal a ese sitio, entre ellos curas, tenientes de gobernador e incluso, administradores. Probablemente, la cuestión se centraba en que había que generar algún cambio para seguir sacando provecho de la fuerza de trabajo indígena. Lo que llama la atención de esta política, no es la idea de desvincularlos del régimen misionero, sino la condena al modelo comunal en sí y a las cautelosas expectativas, depositadas sobre la liberación de los guaraníes.

${ }^{30}$ Las nuevas políticas de gobierno estuvieron asentadas, en un primer momento, en las ordenanzas de Francisco de Paula Bucarelli y Ursúa. Luego en las emanadas de la corona, los virreyes y de los gobernadores de misiones. 
Una contradictoria política en donde la libertad sería dada solo a quienes demostrasen merecerla. Una fabulosa demostración de poder y discriminación bajo la tela conceptual de esquemas liberales ${ }^{31}$.

Por su parte, la terminología y las asociaciones utilizadas por algunos funcionarios o eclesiásticos para argumentar la, ahora imperiosa liberación de los guaraníes de sus cargas de comunidad -que no era otra cosa que desvincularlos de parte de las imposiciones del sistema colonial-, resultaba a primera lectura contundente. Al respecto, el cura del pueblo de San Javier, antigua reducción jesuita, había sentenciado, tal como citamos más arriba, que el sistema de comunidad, privaba del bien más apreciable para el hombre como era la libertad y, que a falta de libertad, les faltaba todo. No obstante, pese a esta claridad conceptual, una multiplicidad de mediaciones se interpusieron para otorgar la libertad a las poblaciones indígenas, aunque resultaba evidente, para la gran mayoría de los actores consultados, que era la base de una vida plena, según los parámetros de bienestar de la época.

Esta cuestión se constituyó en uno de los grandes meollos de la ideología política liberal, que poco a poco, fue condimentando el imaginario local de criollos letrados, ya que al mismo tiempo que se promulgaba la idea de "sujetos nuevos" y la libertad era puesta como bandera, la misma estaba pensada en términos económicos y patrimoniales, más que sociales y políticos. Por el contrario, se esperaba que estos cambios no desarticulasen las antiguas clasificaciones socio/étnicas y sociales del sistema colonial vigente. Al respecto, aunque los procesos independentistas sumaron a la ideología de la libertad, la de igualdad, incentivando la construcción de una ciudadanía republicana, las décadas posteriores a las rupturas del régimen monárquico, no implicaron la extensión real de la misma a las comunidades indígenas en lo que había constituido los antiguos virreinatos del Perú y Río de la Plata.

Los vaivenes y contradicciones en la política indígena colonial, observados en el caso guaraní, también fueron descriptos por la historiografía brasilera. Al respecto, durante la monarquía de José I y la designación como ministro de Estado a Sebastião José de Carvalho e Melo, más conocido como marqués de Pombal, se buscó poner en práctica una nueva política indígena. Ésta, había sido pensada sobre todo para las misiones de Grão-Pará e Maranhão, en la cuenca Amazónica, administrada por órdenes regulares, y que ahora promulgaba la libertad de la población reducida, con el fin de convertirlos en "vasallos del Rey al mismo nivel del resto de los súbditos portugueses"

\footnotetext{
${ }^{31}$ En particular el informe de Miguel de Lastarria, representa en sí mismo las propias contradicciones de muchos sujetos instruidos en las ideas ilustradas de la época en cuanto a los límites dados a la libertad de los "súbditos" de un sistema monárquico de corte absolutista. Esto no solo queda representado en la idea de un sistema "tutelar" para garantizar la liberación de las cargas de comunidad sino en la ratificación del sistema esclavista. Al respecto, Lastarria dedicó una extensa parte de su informe a evaluar la mejor y redituable forma de ejercer el comercio de esclavos africanos. En relación con ello, consideraba que "los varios puntos de esta Providencia, creo, son conducentes al fomento y protección del Comercio de Negros del Río de la Plata, que ocasiona comúnmente aquellos procesos cuyos inconvenientes deben remediarse con la mayor vigilancia por ser dicho Comercio de primera necesidad para Las Américas según lo caracteriza la Real Orden de 2 de Junio de 1787" (Lastarria 1914: 313, Parte II).
} 
(Álvarez Iglesias, 2012: 28). Sin embargo, esta "libertad" debía ser "tutelada" por el llamado "Directorio de indios" (1757-1798), quien estaría a cargo de fomentar el trabajo, la educación, la evangelización, la introducción de la "lengua única", los matrimonios mixtos, la residencia en villas y la asimilación a la sociedad mayor. Esta medida, era impulsada en la coyuntura de la crisis económica y ante los conflictos de intereses entre colonia y metrópoli.

Dentro de este esquema de situación se buscó en un primer momento, quitarle poder y el monopolio que tenían los jesuitas sobre la potencial fuerza de trabajo de esta rica región, así como contar con una población numerosa para poblar las fronteras. Tras la expulsión de los jesuitas de Portugal, en 1759, y más tarde tras el cambio de reinado y la "muerte política" del marqués de Pombal sumado al endurecimiento de las relaciones coloniales, el Directorio fue revocado, y en su lugar, se estableció la llamada "Carta Regia" que permitía la persecución y exterminios de los grupos indómitos, reactualizando el antiguo concepto de "guerra justa" (Álvarez Iglesias, 2012 y Melo Sampaio, 2012). En este sentido, si bien la segunda mitad del siglo XVIII significó un momento de cambio en el escenario jurídico para los pueblos indígenas del Brasil, como advirtieron ciertos estudios precursores del tema (Carneiro de Cunha y Farage, 1987), no tuvo continuidad en la práctica, y por el contrario, dio lugar incluso a un recrudecimiento de políticas coloniales violentas en relación a los grupos no reducidos.

En esta misma línea, la política en torno a la población de las misiones transitó en menos de cincuenta años por un gama diversa e imprecisa de medidas, que si bien irían asumiendo el paradigma general de desarticulación de los sistemas comunales, de la separación entre indígenas y españoles -aunque recreando al mismo tiempo jerarquías de castas y diferenciaciones impositivas y socio/políticas-, y de ampliación del comercio entre los guaraníes -como ya se venía haciendo de hecho en otras zonas indígenas del virreinato-, tuvo sus vaivenes e incluso sus retrocesos. La discusión sobre libertad o dependencia, a un sistema de cargas laborales, no incluyó la libertad en todos los planos y menos la igualdad jurídica. Por su parte, la ocupación del territorio oriental de las misiones por los portugueses cambió totalmente la lógica de la política tibiamente implementada por Avilés, ya que el centro de atención se trasladó hacia la cuestión bélica, pese a que desde el ámbito local no se generaron recursos para revertir la situación de ocupación, y menos aún, surgieron nuevas instancias diplomáticas. Por su parte, los guaraníes de las misiones orientales, ya hacía tiempo que venían construyendo relaciones comerciales o de alianzas políticas con los portugueses de las colonias de Rio Grande (Frühauf Garcia, 2009). De esta forma, como afirman algunos autores su adscripción a uno u otra potestad mostró, en algunos casos, ser una cuestión coyuntural (Wilde, 2003).

Por su parte, los guaraníes de los pueblos, dentro de una gama de posibilidades relacionadas con su oficio, cargo, género y vínculos, fueron recorriendo el abanico de opciones que las nuevas circunstancias económicas, políticas y jurídicas abrieron o cerraron, y dentro de ese universo tras un manto de políticas de índole general, continuaron desenvolviéndose de acuerdo a lógicas familiares o grupales en los años 
posteriores al decreto de Avilés y a la toma del territorio oriental por los portugueses. Pocos años después, la revolución de Mayo abrió un breve período de integración y revalorización del sistema comunal en torno a los pueblos guaraníes, ahora asentados en las fronteras de jurisdicciones en pugna. Esto, como parte de un conjunto de consignas ideológicas de cambio político y, como necesidad de ampliar la ciudadanía a toda la población, potenciales aliados y milicianos en la lucha contra el antiguo régimen. En esta coyuntura de transición, entre vasallos y ciudadanos, un imaginario de restitución del ideal misionero, en base a la fuerza de la comandancia bélica de ciertos líderes guaraníes, convocó a un número sustancial de familias que habían pertenecido a la antigua región misionera en la lucha por conquistar nuevos y viejos tiempos. Momentáneamente se fundaron nuevos pueblos mientras que otras familias iniciaron un cambio individual de integración desigual a la sociedad mayor.

\section{Referencias bibliografícas}

Alvarez Iglesias, Rubén. 2012. "Entre la asimilación y el exterminio: los indios de Brasil desde el 'Diretório' hasta la abolición de la esclavitud indígena (c. 1750-1845)". CT 4, Universidad Nova de Lisboa, pp. 21-44.

Alvear, Diego. [1791] 1970. "Relación Geográfica e Histórica de Misiones". En Pedro de Angelis (comp.). Colección de obras y documentos relativos a la historia antigua y moderna de las provincias del Río de la Plata. Buenos Aires, Editorial Plus Ultra, pp. 579-727.

Azara, Félix. 1941. Viajes por la América Meridional. Madrid, Espasa-Calpe.

Cunha, Manuela Carneiro y Farage, Nádia. 1987. "Caráter da tutela dos índios: orígenes e metamorfoses". En Manuela Carneiro da Cunha. Os direitos dos Indios: ensaios e documentos (ed). Sao Paulo, Brasiliense, pp. 103-118.

Doblas, Gonzalo de. [1785] 1970. "Memoria sobre la Provincia de Misiones de indios Guaraníes", Pedro de Angelis (comp.). 1970., Colección de obras y documentos relativos a la historia antigua y moderna de las provincias del Río de la Plata, Buenos Aires, Editorial Plus Ultra, pp. 23-187.

Frühauf García. 2007. As diversas formas de Ser Indio. Políticas indígenas y políticas indigenistas no extremo sul da América portuguesa, Rio de Janeiro, Arquivo Nacional.

Ganson, Bárbara. 2003. The Guarani under Spanish Rule in the Rio de la Plata, Stanford, Stanford University Press.

Hernández, Juan Luis. 1999. "Tumultos y motines. La conflictividad social en los pueblos guaraníes de la región misionera (1768-1799)", Memoria Americana, 8, Buenos Aires: Facultad de Filosofía y Letras, pp. 83-100. . 2002. "Las reformas del virrey Avilés en los pueblos guaraníes de Misiones (17991801)". Prohistoria, (jan 1), Rosario, pp. 11-34.

Lastarria, Miguel de. 1914. Colonias orientales del Río Paraguay o de la Plata, Buenos Aires, Instituto de Investigaciones Históricas, Facultad de Filosofía y Letras, Vol. III.

Maeder, Ernesto. 1992. Misiones del Paraguay, conflicto y disolución de la sociedad guaraní, Madrid, Mapfre.

Mariluz Urquijo, José María. [1964] 1987. El virreinato del Río de la Plata en la época del virrey Avilés (1799-1800), Buenos Aires, Plus Ultra.

. 1953. "Los guaraníes después de la expulsión de los jesuitas", Estudios Americanos 6 (25), Madrid, CSIC, pp. 323-330. 
Melo Sampaio, Patricia. 2012. "Fronteras de la libertad. Tutela indígena en el Directorio pombalino y en la Carta Regia de 1798", Boletín Americanista, Año LXII. 1, n. ${ }^{\circ} 64$, Barcelona, pp. 13-23.

Poenitz, Edgar y Alfredo Poenitz. 1998. Misiones, Provincia Guaranítica. Defensa y Disolución (1768-1830), Posadas, Editorial Universitaria.

Quarleri, Lía. 2009. Rebelión y guerra en las fronteras del Plata. Guaraníes, Jesuitas e Imperios coloniales, Buenos Aires, Fondo de Cultura Económica. . 2011. "Expediciones, narrativas y utopias. Nuevas miradas sobre el "espacio guaranímisionero (1784-1796)", ANTITESES Vol. 4, n 8, Londrina, Universidade Estadual de Londrina, pp. 753-782.

.2012. Políticas borbónicas en los “pueblos de indios guaraníes" estratificación, mestizaje e integración selectiva. Nuevo Mundo, Mundos Nuevos, Cerma - Mondes américains École des hautes études en sciences sociales. http://nuevomundo.revues.org/64459

Rosas Moscoso, Fernando. 2008. Del Río de la Plata al Amazonas. El Perú y el Brasil en la época de la dominación ibérica, Lima, Editorial Universitaria.

Sarreal, Sarreal. 2008. "Los guaraníes y el colapso del régimen comunitario de las misiones, 1768-1800". XII Jornadas Internacionales sobre las Misiones Jesuiticas: Interacciones y sentidos de la conversión. Manzana de las Luces, Buenos Aires, 2008, (cd-room).

Susnik, Branislava. 1966. El Indio Colonial del Paraguay II: Los trece pueblos guaraníes de las Misiones (1767-1803), Asunción, MEAB.

Wilde, Guillermo. 2001. "Los guaraníes después de la expulsión de los jesuitas. Dinámicas políticas y prácticas simbólicas", Revista Complutense de Historia de América 27, Madrid, Universidad Coimplutense, pp. 69-109.

Wilde, Guillermo. 2003. "Guaraníes, "gauchos" e "indios infieles" en el proceso de disgregación de las antiguas doctrinas jesuíticas del Paraguay", Suplemento Antropológico XXXVIII (2), Asunción, pp. 78-77. 